\title{
Analisis Analisis Faktor-Faktor Yang Mempengaruhi Dalam Penilaian Kinerja Sistem Jaringan Irigasi Pada Daerah Irigasi Wawotobi di Kabupaten Konawe Provinsi Sulawesi Tenggara
}

\author{
Amriyadi, Edijatno, Theresiah Sri Sidharthi \\ Program Studi S2 Teknik Sipil MRSA FTSP ITS \\ email:amriyadi13@mhs.ce.its.ac.id
}

\begin{abstract}
Abstrack
Konawe known as an area that plays an important role in agricultural production in Southeast Sulawesi particularly rice and pulses.

Most of Irrigation in Indonesia has not been optimal in the management as influenced by several factors that need to be examined, one of which has not been optimal in performance management is Wawotobi Irrigation Area. Irrigation area is currently carried out by the technical manager Wawotobi BWS Sulawesi IV, Directorate General of Water Resources, Ministry of Public Works and Public Housing. Irrigation area Wawotobi gets water supply from the dam on the river Wawotobi Konaweha with extensive irrigation area 16572.26 hectares. The research objective is to analyze the performance of the existing condition in the Regional Irrigation Irrigation Wawotobi and analyze Factors Affecting the Performance Appraisal System for Irrigation in Irrigation Area Wawotobi by the community of users farmers. Determine the scoring and highly significant indicator of the Factors Affecting the Performance Appraisal System for Irrigation in Irrigation Area Wawotobi.

The study was conducted on a performance appraisal system that includes Irrigation Irrigation Water, Physical Infrastructure Irrigation, Irrigation Management System, Institute of Irrigation Management and business major level with reference to the Candy PUPR No. 30/PRT/M/2015. Methods The study was conducted by means of direct observation, questionnaires and testing, analytical tools used in the study is Analytical Hierarchy Process (AHP). Based on a study of existing conditions, water supply sufficient to meet the needs of farmers, Infrastructures excellent condition, Irrigation Management that need to be optimized especially the growing season to be performed optimally and the opening of new land that is completely not go according to plan, Institutional Managers need to continue to build good relations between relevant agencies, quality and quantity need to be maintained and enhanced for business Top level.

Based on the results of the assessment on Irrigation Area Wawotobi involving farmers (P3A ) by taking a sample of 115 respondents in the three sub-systems that exist in of Regional Irrigation Wawotobi it can be obtained as follows : Sub System III Regional Intake Left Bungguosu have good performance with a value of 77.88. Sub System II Regional Intake Left Unaaha Unaaha A and $B$ had a good performance with a value of 74.90 and the Sub Regional Intake System I Uepai Right Tawamelewe have good performance with a value of 72.84.

Based on the assessment on the 3rd Sub System in Irrigation Area Wawotobi the average characteristics of the problems facing the same one with the other is a system of cropping patterns are not optimal, most of the potential land uncultivated manjadi land functional because of limited funding from both the central and local levels; some people still maintain their land as plantations for other plants, processing equipment field is still limited, as well as land conversion potential, especially in Sub System II .
\end{abstract}

Keywords : Irrigation Area Wawotobi, Sub Systems I,II,III, Analytical Hierarchy Process 


\begin{abstract}
Abstrak
Kabupaten Konawe dikenal sebagai daerah yang berperan penting dalam produksi pertanian di Provinsi Sulawesi Tenggara khusunya padi dan palawija

Sebagian Jaringan Irigasi (JI) yang ada di Indonesia belum optimal dalam pengelolaan karena dipengaruhi beberapa faktor yang perlu dikaji, salah satu diantaranya yang belum optimal dalam pengelolaan kinerjanya adalah Daerah Irigasi (DI) Wawotobi. Saat ini DI Wawotobi pengelola teknisnya dilaksanakan oleh BWS Sulawesi IV, Ditjen SDA, Kementerian Pekerjaan Umum dan Perumahan Rakyat. DI Wawotobi mendapat suplai air dari Bendung Wawotobi pada sungai Konaweha dengan luas DI 16.572,26 Ha. Tujuan penelitian adalah menganalisa kondisi eksisting kinerja JI di DI Wawotobi dan menganalisa Faktor-faktor yang Mempengaruhi dalam Penilaian Kinerja Sistem JI pada DI Wawotobi oleh masyarakat pengguna/petani. Menentukan skoring dan indikator yang sangat signifikan terhadap Faktor-faktor yang Mempengaruhi dalam Penilaian Kinerja Sistem JI pada DI Wawotobi.

Penelitian dilakukan pada penilaian kinerja Sistem JI yang mencakup Air Irigasi, Prasarana Fisik Irigasi, Sistem Pengelolaan Irigasi, Institusi Pengelola Irigasi dan Pengelola diTingkat Utama/SDM dengan mengacu pada Permen PUPR No. 30/PRT/M/2015. Metode Penelitian dilakukan dengan cara observasi langsung, kuisoner dan pengujian, alat analisis yang digunakan dalam penelitian adalah metode Analytical Hierarchy Process (AHP).

Berdasarkan hasil penilaian pada DI Wawotobi yang melibatkan petani (P3A) dengan pengambilan sampel sebanyak 115 responden pada 3 Sub Sistem yang ada di DI Wawotobi maka dapat diperoleh hasil sebagai berikut : Sub Sistem III Wilayah Intake Kiri Bungguosu memiliki kinerja baik dengan nilai 77,88, Sub Sistem II Wilayah Intake Kiri Unaaha A dan Unaaha B memiliki kinerja baik dengan nilai 74,9 dan Sub Sistem I Wilayah Intake Kanan Uepai Tawamelewe memiliki kinerja baik dengan nilai 72,84.

Berdasarkan penilaian pada ke 3 Sub Sistem yang ada di Daerah Irigasi Wawotobi ratarata karekteristik permasalahan yang dihadapi sama satu dengan yang lainnya yaitu sistem pola tanam yang belum optimal, sebagian lahan potensial belum diolah manjadi lahan fungsional karena keterbatasan dana baik dari pusat maupun daerah, sebagian masyarakat masih mempertahankan lahan mereka sebagai lahan perkebunan untuk tanaman lainnya, alat pengolah sawah masih terbatas, serta alih fungsi lahan potensial khususnya di Sub Sistem II.
\end{abstract}

Kata kunci : Daerah Irigasi Wawotobi, Sub Sistem I,II, III, Analytical Hierarchy Process

\section{Pendahuluan}

Daerah Irigasi dan bendung Wawotobi di Kabupaten Konawe Sulawesi Tenggara dibangun pada tahun $1981 \mathrm{~s} / \mathrm{d} 1987$ dan merupakan salah satu irigasi teknis yang terbesar yang ada di Sulawesi Tenggara sampai saat ini, DI Wawotobi mengambil sumber air dari bendung Wawotobi di Kabupaten Konawe Provinsi Sulawesi Tenggara.

DI Wawotobi berdasarkan perencanaan awal diharapkan mampu mengairi lahan dengan potesi $18.000 \mathrm{Ha}$. Namun selama kurang waktu lebih 27 tahun perkembangan luas potensial eksisting baru mencapai 16.572,26 Ha serta luas fungsional eksisting 9.872,54 $\mathrm{Ha}$, sehingga antara luas potensial eksisting dengan luas pontensi awal desain masih memiliki perbedaan 1.427,74 Ha., demikian pula perbedaan luas potensial eksisting dengan luas fungsional eksisting masih memiliki rentang jarak luas yang cukup tinggi yaitu 6.699,72 $\mathrm{Ha}$, begitu pula jika dibandingkan dengan desain awal luas potensial yang diharapkan mampu diairi tentu jaraknya semakin jauh dengan luas fungsional 
yang ada sampai saat ini dengan perbedaan luas sekitar $8.127,46 \mathrm{Ha}$, hal ini menunjukkan kinerja sistem JI di DI Wawotobi belum berjalan optimal, sehingga dapat berdampak terhadap kinerja dan fungsi pelayanan JI, produktiftias pertanian khususnya padi sawah, perekonomian Kabupaten Konawe pada umumnya dan khususnya pendapatan petani sawah yang ada di DI Wawotobi. Adapun faktor yang menyebabkan antara lain : masih banyak lahan potensial yang belum diolah menjadi sawah, pola tanan yang belum optimal, alih fungsi lahan potensial, serta alat pengolah sawah masih terbatas.

\subsection{Lokasi Studi}

Lokasi penelitian adalah Jaringan Irigasi di Daerah Irigasi Wawotobi Kabupaten Konawe Provinsi Sulawesi Tenggara seperti pada Gambar 1.1. berikut ini :

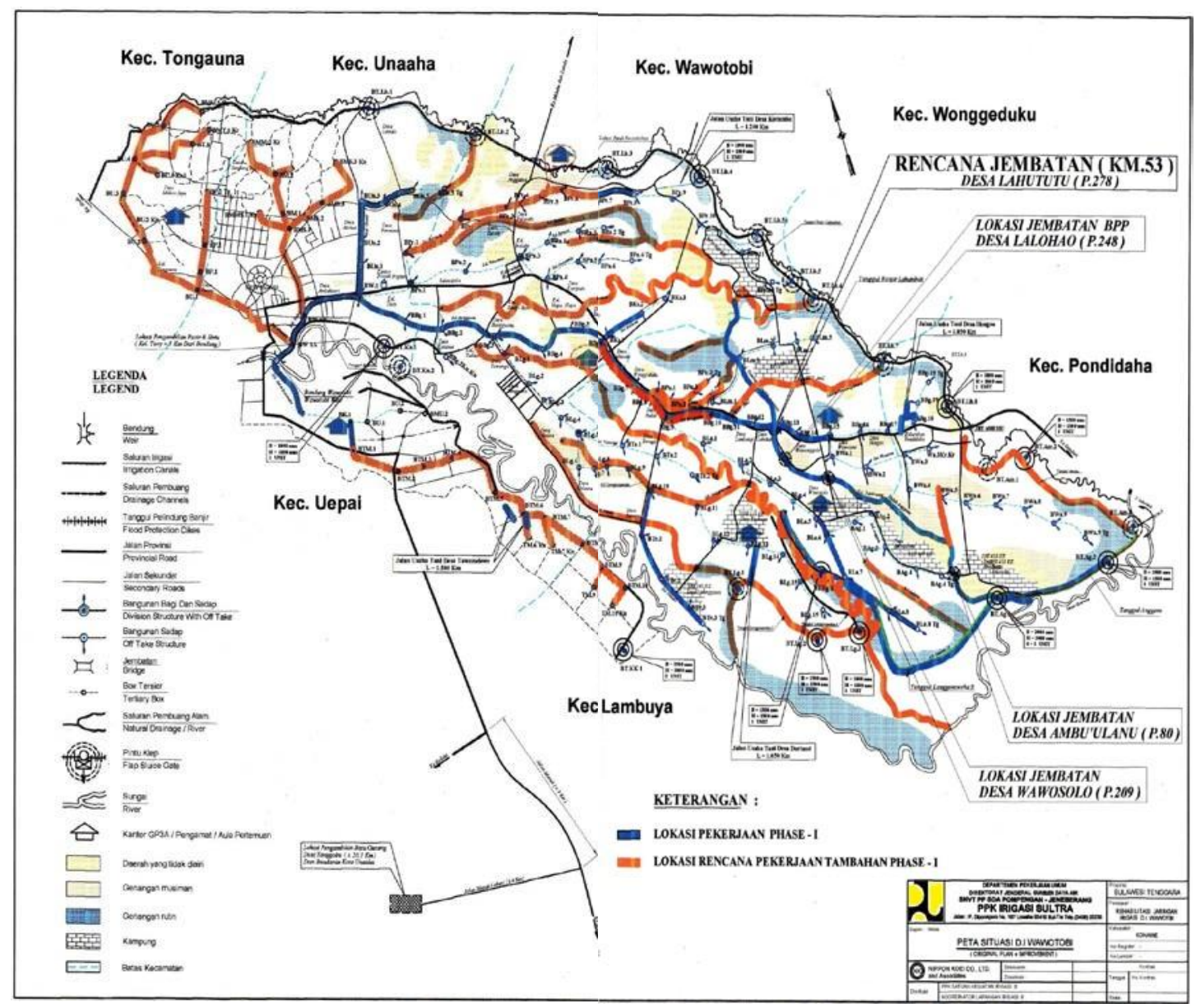

Gambar 1.1. Skema Jaringan Irigasi 
Daerah Irigasi Wawotobi terletak diperbatasan Kecamatan Unaaha dan Kecamatan Uepai Kabupaten Konawe, berjarak $73 \mathrm{~km}$ dari Kota Kendari ibukota Provinsi Sulawesi Tenggara dengan waktu tempuh kurang lebih 1 setengah jam perjalanan melalui jalan nasional lintas provinsi dengan koneksitas Provinsi Sulawesi Selatan, Provinsi Sulawesi Tengah dan Provinsi Sulawesi Tenggara, kondisi jalan saat ini $100 \%$ aspal dan $85 \%$ kategori mantap. JI Wawotobi dioperasikan pada tahun 1988 terdiri dari saluran pembawa sepanjang $139 \mathrm{~km}$, dengan 107 buah bangunan sadap, 12 buah bangunan bagi sadap, 2 buah bangunan bagi, 278 buah bangunan pelengkap dan 223 petak tersier.

JI Wawotobi pada tahun 2014 telah berkembang menjadi : saluran pembawa sepanjang 153.154,83 m, dengan 207 buah bangunan sadap, 14 buah bangunan bagi sadap, 4 buah bangunan bagi, 724 buah bangunan pelengkap dan b dan 260 petak tersier, adapun luas potensial yang telah dicapai 16.572,26 ha. dan luas fungsional 9.072,54 Ha.

\subsection{Data Teknis}

Data teknis tentang DI Wawotobi :

1. Luas areal potensial : $16.572,26 \mathrm{Ha}$

2. Luas areal fungsional : $9.872,54 \mathrm{Ha}$

3. Panjang saluran : $153.155,83 \mathrm{~m}$

4. Bangunan sadap : 207
5. Bangunan bagi : 4 bh

6. Bangunan bagi sadap : 14 bh

7. Bangunan pelengkap : $724 \mathrm{bh}$

8. Saluran pembuang : $130 \mathrm{~km}$

9. Tanggul banjir : $91 \mathrm{~km}$

10. Type bendung : Bendung tetap dengan mercu type Ogee dengan konstruksi benton bertulang.

11. Lebar bendung : $99,00 \mathrm{~mm}$

12. Tinggi mercu : $3,00 \mathrm{~m}$

13. Type kolam olakan: USBR type III

14. Panjang kolam olakan : $22,00 \mathrm{~m}$

15. Lebar pintu intake :

- Kanan 1 x 1,70 m

- Kiri 1 x 1,70 m

16. Lebar pintu penguras

- Kanan 2,2,33 m

- Kiri 3,2,33 m

17. Panjang lantai depan $30,00 \mathrm{~m}$

18. Elevasi lantai depan $+36,40 \mathrm{~m}$

19. Elevasi mercu : $+39,40 \mathrm{~m}$

20. Elevasi kolam olakan : $+34,40 \mathrm{~m}$

21. Elevasi dekster pintu intake: $+45,60$ $\mathrm{m}$.

\section{Metodologi}

Penelitian ini dilakukan untuk memperoleh gambaran mengenai kondisi eksisting unsus unsur dari sistem irigasi pada DI Wawotobi guna mendapatkan faktor faktor yang berpengaruh dalam kinerja kemudian menilai kondisi kinerja masing masing Sub Sistem dan untuk lebih jelasnya dapat dilihat pada diagram alir gambar 1.2. 


\section{ISSN.1907-753X}

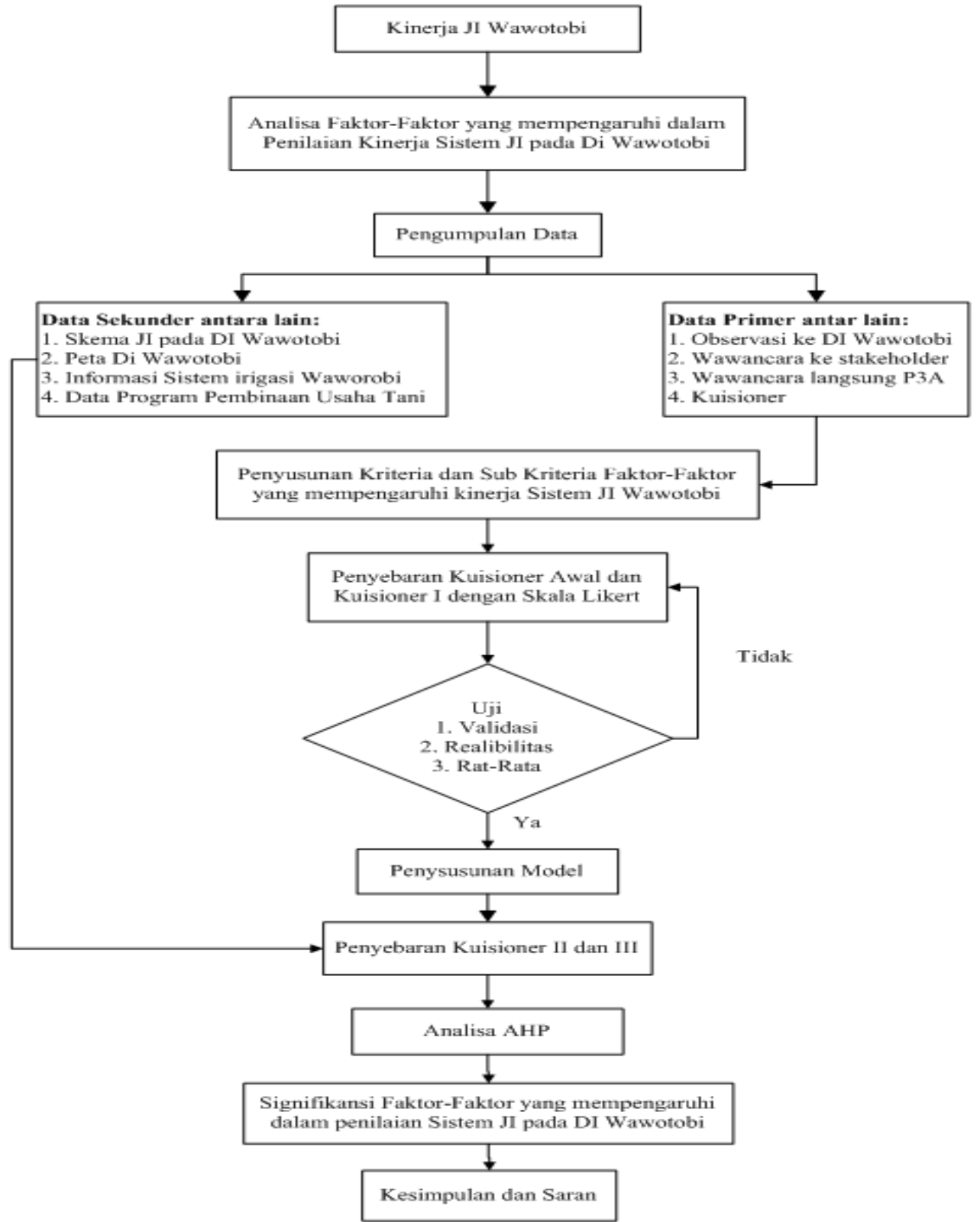

Gambar 1.2. Diagram Alir Penelititan

Diagram alir penelitian ini terdiri dari 6 tahapan, yakni tahap I menetapkan rumusan masalah, tahap II studi literatur, melakukan identifikasi variabel awal dan kajian pustaka kemudian menentukan pohon hirarki, tahap III pengempulan data dengan menggunakan motode wawancara dan dokumentasi serta penyebaran kuisioner untuk para pakar/ahli, tahap IV merupakan tahap analisa data menggunakan AHP, sofware yang digunakan dalam penelitian ini adalah Expert Choice 11 untuk memperoleh tingkat prioritas masing masing variabel sehingga diperoleh bobot prioritas, tahap $\mathrm{V}$ melakukan analisa penilaian kinerja masing- masing 
sub Sistem. Tahap VI adalah panarikan kesimpulan dan saran.

\section{Hasil dan Pembahasan}

Penilaian bobot indikator dengan menggunakan metode AHP.

Hasil penilaian Bobot Kinerja dengan menggunakan 5 kriteria yang ada serta untuk lebih jelasnya dapat dilihat pada
Tabel 3.1. dan 3.2.

Tabel 3.1. Hasil Nilai Bobot 5 Kriteria

\begin{tabular}{lll}
\hline No. & Kriteria & Bobot \\
\hline 1 & Air Irigasi & 0.219 \\
2 & Sarana dan Prasarana & 0,227 \\
3 & Manajemen Irigasi & 0,201 \\
4 & Institusi Pengelola Irigasi & 0,204 \\
5 & Pengelola/ SDM & 0,150
\end{tabular}

Tabel 3.2. Nilai Bobot Sub Kriteria






\begin{tabular}{cccccccc}
$\begin{array}{c}\text { Hubungan antar } \\
\text { Masyarakat }\end{array}$ & P3 & 0,088 & 0,9712 & 4 & 0,0132 & 23 \\
Regenerasi & P4 & 0,158 & 1,0238 & 3 & 0,0236 & 16 \\
\hline
\end{tabular}

Kemudian untuk mendapatkan nilai prioritas di urut sesuai dengan nilai tertinggi hingga terendah sebagaimana pada tabel 3.3. berikut :

Tabel 3.3. Urutan Prioritas Nilai Bobot

\begin{tabular}{|c|c|c|c|c|}
\hline No & Sub Kriteria & Kode & $\begin{array}{c}\text { Total } \\
\text { Bobot }\end{array}$ & $\begin{array}{c}\text { Urutan } \\
\text { Prioritas }\end{array}$ \\
\hline 1 & Dinas PU dan Subdin SDA & I1 & 0,0952 & 1 \\
\hline 2 & Ketersediaan Debit & A1 & 0,0902 & 2 \\
\hline 3 & Kondisi dan Fungsi JI & $\mathrm{S} 1$ & 0,0797 & 3 \\
\hline 4 & Kuantitas & $\mathrm{P} 1$ & 0,0723 & 4 \\
\hline 5 & Periode Pembagian Air & M2 & 0,0619 & 5 \\
\hline 6 & Sistem Penyediaan Air & A3 & 0,0571 & 6 \\
\hline 7 & Unit Pelaksana Teknis Daerah & $\mathrm{I} 3$ & 0,0566 & 7 \\
\hline 8 & Saluran Pembawa & $\mathrm{S} 2$ & 0,0491 & 8 \\
\hline 9 & Perencanaan Pola Tanam & M3 & 0,044 & 9 \\
\hline 10 & Kualitas/ Kopetensi & $\mathrm{P} 2$ & 0,0407 & 10 \\
\hline 11 & Saluran Pembuang & $\mathrm{S} 3$ & 0,0367 & 11 \\
\hline 12 & Komisi Irigasi & $\mathrm{I} 2$ & 0,0329 & 12 \\
\hline 13 & Pemeliharaan dan Rehabilitasi & M5 & 0,0297 & 13 \\
\hline 14 & Stabilitas Penyediaan Air & A4 & 0,027 & 14 \\
\hline 15 & Bangunan dan Saluran Pembawa & S4 & 0,0245 & 15 \\
\hline 16 & Regenerasi & $\mathrm{P} 4$ & 0,0236 & 16 \\
\hline 17 & Kualitas Air Irigasi & $\mathrm{A} 2$ & 0,0224 & 17 \\
\hline 18 & Kehilangan Air & A5 & 0,0221 & 18 \\
\hline 19 & Partisipasi Petani & M4 & 0,022 & 19 \\
\hline 20 & Petani Pengguna Air & I4 & 0,0196 & 20 \\
\hline 21 & Jalan Inspeksi & S5 & 0,0162 & 21 \\
\hline 22 & Iuran OP & M6 & 0,0159 & 22 \\
\hline 23 & Hubungan antar Masysrakat & P3 & 0,0132 & 23 \\
\hline 24 & $\begin{array}{c}\text { Pengumpulan Data, Perhitungan, } \\
\text { Kebutuhan Air }\end{array}$ & M1 & 0,0107 & 24 \\
\hline 25 & Kantor Perumahan, Gudang & S6 & 0,0096 & 25 \\
\hline 26 & Sisitem Informasi dan Monitoring & M7 & 0,0074 & 26 \\
\hline 27 & Peralatan Penunjang OP & S7 & 0,0068 & 27 \\
\hline 28 & Sisitem Pengambilan Keputusan & M8 & 0,0051 & 28 \\
\hline 29 & Sistem Insentif dan Disentif & M9 & 0,0038 & 29 \\
\hline
\end{tabular}


Prioritas dan nilai bobot yang telah didapatkan akan digunakan untuk melakukan penilaian Kinerja Jaringan Irigasi pada masing masing Sub Sistem.

\subsection{Hasil Penilaiaian DI Wawotobi}

Analisa penilaian indikator terhadap JI di DI Wawotobi yang dilakukan oleh petani sebagai pengguna Jaringan Irigasi dimaksudkan untuk menilai Faktorfaktor yang Mempengaruhi Kinerja Sistem JI di DI Wawotobi.

\section{Sub Sistem I}

Sub sistem I memiliki urutan nilai sebagai berikut :
a. Aspek Air Irigasi menempati urutan pertama dengan nilai 16,64 ,

b. Aspek Sarana dan Prasarana Fisik urutan kedua dengan nilai 16,57 ,

c. Aspek Institusi Pengelola di urutan ketiga dengan nilai 15,28

d. Aspek Manajemen Irigasi urutan keempat dengan nilai 14,35 dan,

e. Aspek Pengelola diTingkat Utama/SDM kelima dengan nilai 10,1 
Tabel 3.4 Hasil Perhitungan Sub Sistem I

\begin{tabular}{|c|c|c|c|c|c|}
\hline \multirow{2}{*}{ No } & \multirow{2}{*}{ Kode } & \multirow{2}{*}{ Sub Kriteria } & \multirow{2}{*}{$\begin{array}{c}\text { Bobot Sub } \\
\text { Kriteria }\end{array}$} & \multicolumn{2}{|c|}{ Sub Sistem I } \\
\hline & & & & $\begin{array}{c}\text { Nilai } \\
\text { Petani } \\
\end{array}$ & Total \\
\hline 1 & 2 & 3 & 4 & 5 & $\begin{array}{c}6=4 x \\
5\end{array}$ \\
\hline 1 & A1 & Ketersediaan Debit & 0,0902 & 76,33 & 6,89 \\
\hline 2 & $\mathrm{~A} 2$ & Kualitas Air Irigasi & 0,0224 & 78,2 & 1,75 \\
\hline 3 & A3 & Sistem, Penyediaan Air & 0,0571 & 74 & 4,22 \\
\hline 4 & A4 & Stabilitas Penyediaan & 0,027 & 74,67 & 2,01 \\
\hline \multirow[t]{2}{*}{5} & A5 & Kehilangan Air & 0,0221 & 79,67 & 1,76 \\
\hline & & Air Irigasi & 0,219 & & 16,64 \\
\hline 1 & $\mathrm{~S} 1$ & Kondisi dan Fungsi Jaringan & 0,0797 & 74 & 5,9 \\
\hline 2 & $\mathrm{~S} 2$ & Saluran Pembawa & 0,0491 & 76 & 3,73 \\
\hline 3 & S3 & Bangunan pada Saluran Pembawa & 0,0367 & 79 & 2,9 \\
\hline 4 & $\mathrm{~S} 4$ & Saluran Pembuang dan Bangunannya & 0,0245 & 75,53 & 1,85 \\
\hline 5 & S5 & Jalan Inspeksi & 0,0162 & 67,27 & 1,09 \\
\hline 6 & S6 & Kantor, Perumahan, Gudang & 0,0096 & 69,13 & 0,66 \\
\hline \multirow[t]{2}{*}{7} & S7 & Peralatan Penunjang OP & 0,0068 & 64,13 & 0,44 \\
\hline & & Sarana dan Prasarana Fisik & 0,223 & & 16,57 \\
\hline 1 & M1 & Pengumpulan Data, Pembagian Air & 0,0107 & 67,2 & 0,72 \\
\hline 2 & M2 & Priode Pembagian Air & 0,0619 & 74,67 & 4,62 \\
\hline 3 & M3 & Rencana Pola Tanam & 0,044 & 71,33 & 3,14 \\
\hline 4 & M4 & Partisipasi Petani & 0,022 & 70,67 & 1,56 \\
\hline 5 & M5 & Pemeliharaan dan Rehabilitasi & 0,0297 & 71 & 2,11 \\
\hline 6 & M6 & Iuran OP & 0,0159 & 66,27 & 1,05 \\
\hline 7 & M7 & Sistem Informasi dan Monitoring & 0,0074 & 66,6 & 0,5 \\
\hline 8 & M8 & Sistem Pengambilan Keputusan & 0,0051 & 71,6 & 0,36 \\
\hline \multirow[t]{2}{*}{9} & M9 & Penerapan Sistem Insentif dan Disentif & 0,0038 & 77 & 0,29 \\
\hline & & Manajemen Irigasi & 0,201 & & 14,35 \\
\hline 1 & $\mathrm{I} 1$ & Dinas PU Subdin SDA Kabupaten & 0,0952 & 74,6 & 7,1 \\
\hline 2 & $\mathrm{I} 2$ & Komisi Irigasi & 0,0329 & 77 & 2,53 \\
\hline 3 & $\mathrm{I} 3$ & Unit Pelaksana Teknis & 0,0566 & 74,27 & 4,21 \\
\hline \multirow[t]{2}{*}{4} & $\mathrm{I} 4$ & Perkumpulan Petani Pengguna Air & 0,0196 & 73,33 & 1,44 \\
\hline & & Institusi Pengelola Irigasi & 0,204 & 299,2 & 15,28 \\
\hline 1 & $\mathrm{P} 1$ & Kuantitas & 0,0723 & 67,33 & 4,87 \\
\hline 2 & $\mathrm{P} 2$ & Kualitas (Kompetensi) & 0,0407 & 64 & 2,61 \\
\hline 3 & $\mathrm{P} 3$ & Hubungan antar Masyarakat & 0,0132 & 70,67 & 0,93 \\
\hline \multirow[t]{2}{*}{4} & $\mathrm{P} 4$ & Regenerasi & 0,0236 & 67,93 & 1,6 \\
\hline & & Pengelola di Tingkat Utama/ SDM & 0,15 & & 10,01 \\
\hline
\end{tabular}


Dari hasil penilaian pada Sub Sistem I JI DI Wawotobi dapat dijelaskan sebagai berikut :

a. Kondisi aset sarana dan prasarana yang terdapat pada Sub Sistem I Intake Kanan dalam keadaan terpelihara sangat baik, dari 123 aset yang ada pada wilayah tersebut $100 \%$ dapat berfungsi dengan baik sebagaimana mestinya.

b. Panjang saluran yang terdapat dalam Sub Sistem I sepanjang 19,015,82.m $100 \%$ berfungsi dengan baik.

c. Organisasi yang ada pada wilayah Sub Sistem I berjalan dengan baik karena telah terbentuk GP3A Tamesandi yang membawahi 2 kelompok P3A yaitu P3A Harapan Baru dan P3A Metudui yang ada diwilayah Uepai dan Tawamele. Dengan terbentuknya
GP3A Tamesandi dapat mewadahi dan mengakomodir segala kebutuhan dan persoalan yang ada baik antar kelompok tani maupun dengan pihak lain termasuk petugas lapangan dan pemerintah setempat, serta diharapkan dapat menjadi kelompok tani yang mandiri memenuhi segala kebutuhan rumah tangga kelompok mereka sendiri.

\section{Sub Sistem II.}

Sub sistem II dari hasil penilaian memiliki urutan nilai sebagai berikut :

a. Aspek Air Irigasi menempati urutan pertama dengan nilai 17,64

b. Aspek Institusi Pengelola urutan kedua dengan nilai 15,74.

c. Aspek Sarana dan Prasarana Fisik urutan ketiga dengan nilai 15,73.

d. Aspek Manajemen Irigasi urutan keempat dengan nilai 15,14.

e. Aspek Pengelola diTingkat Utama diurutan kelima dengan nilai 10,65. 
Tabel 3.5 Hasil Perhitungan Sub Sistem II

\begin{tabular}{|c|c|c|c|c|c|}
\hline \multirow{2}{*}{ No } & \multirow{2}{*}{ Kode } & \multirow{2}{*}{ Sub Kriteria } & \multirow{2}{*}{$\begin{array}{c}\text { Bobot Sub } \\
\text { Kriteria } \\
\end{array}$} & \multicolumn{2}{|c|}{ Sub Sistem II } \\
\hline & & & & $\begin{array}{c}\text { Nilai } \\
\text { Petani }\end{array}$ & Total \\
\hline 1 & 2 & 3 & 4 & 5 & $\begin{array}{c}6=4 \times \\
5\end{array}$ \\
\hline 1 & A1 & Ketersediaan Debit & 0,0902 & 80,2 & 7,23 \\
\hline 2 & $\mathrm{~A} 2$ & Kualitas Air Irigasi & 0,0224 & 84,6 & 1,89 \\
\hline 3 & A3 & Sistem, Penyediaan Air & 0,0571 & 80,07 & 4,57 \\
\hline 4 & A4 & Stabilitas Penyediaan & 0,027 & 80,53 & 2,17 \\
\hline \multirow[t]{2}{*}{5} & A5 & Kehilangan Air & 0,0221 & 79,87 & 1,77 \\
\hline & & Air Irigasi & 0,219 & & 17,64 \\
\hline 6 & S1 & Kondisi dan Fungsi Jaringan & 0,0797 & 72,67 & 5,79 \\
\hline 7 & S2 & Saluran Pembawa & 0,0491 & 70,8 & 3,47 \\
\hline 8 & S3 & Bangunan pada Saluran Pembawa & 0,0367 & 72,13 & 2,65 \\
\hline 9 & S4 & Saluran Pembuang dan Bangunannya & 0,0245 & 66,67 & 1,63 \\
\hline 10 & S5 & Jalan Inspeksi & 0,0162 & 68,93 & 1,12 \\
\hline 11 & S6 & Kantor, Perumahan, Gudang & 0,0096 & 65,93 & 0,63 \\
\hline \multirow[t]{2}{*}{12} & S7 & Peralatan Penunjang OP & 0,0068 & 63,87 & 0,44 \\
\hline & & Sarana dan Prasarana Fisik & 0,223 & & 15,73 \\
\hline 13 & M1 & Pengumpulan Data, Pembagian Air & 0,0107 & 67,67 & 0,73 \\
\hline 14 & M2 & Priode Pembagian Air & 0,0619 & 79,13 & 4,89 \\
\hline 15 & M3 & Rencana Pola Tanam & 0,044 & 85,53 & 3,77 \\
\hline 16 & M4 & Partisipasi Petani & 0,022 & 66,47 & 1,46 \\
\hline 17 & M5 & Pemeliharaan dan Rehabilitasi & 0,0297 & 70,2 & 2,09 \\
\hline 18 & M6 & Iuran OP & 0,0159 & 68,6 & 1,09 \\
\hline 19 & M7 & Sistem Informasi dan Monitoring & 0,0074 & 62,8 & 0,47 \\
\hline 20 & M8 & Sistem Pengambilan Keputusan & 0,0051 & 74,53 & 0,38 \\
\hline \multirow[t]{2}{*}{21} & M9 & Penerapan Sistem Insentif dan Disentif & 0,0038 & 69,07 & 0,26 \\
\hline & & Manajemen Irigasi & 0,201 & & 15,14 \\
\hline 22 & $\mathrm{I} 1$ & Dinas PU Subdin SDA Kabupaten & 0,0952 & 75,8 & 7,21 \\
\hline 23 & $\mathrm{I} 2$ & Komisi Irigasi & 0,0329 & 78,13 & 2,57 \\
\hline 24 & $\mathrm{I} 3$ & Unit Pelaksana Teknis & 0,0566 & 79,87 & 4,52 \\
\hline \multirow[t]{2}{*}{25} & $\mathrm{I} 4$ & Perkumpulan Petani Pengguna Air & 0,0196 & 73,2 & 1,44 \\
\hline & & Institusi Pengelola Irigasi & 0,204 & & 15,74 \\
\hline 26 & P1 & Kuantitas & 0,0723 & 70,6 & 5,1 \\
\hline 27 & $\mathrm{P} 2$ & Kualitas (Kompetensi) & 0,0407 & 74,8 & 3,05 \\
\hline 28 & $\mathrm{P} 3$ & Hubungan antar Masyarakat & 0,0132 & 70,8 & 0,94 \\
\hline \multirow[t]{2}{*}{29} & P4 & Regenerasi & 0,0236 & 66,47 & 1,57 \\
\hline & & Pengelola di Tingkat Utama/ SDM & 0,15 & & 10,65 \\
\hline
\end{tabular}


Dari hasil penilaian pada Sub Sistem II JI DI Wawotobi dapat dijelaskan sebagai berikut :

a. Kondisi aset sarana dan prasarana yang terdapat pada Sub Sistem II Intake Kiri Unaaha A dan B sebagian besar dalam kondisi baik, dari 283 aset yang ada pada wilayah Sub Sistem II terdapat 270 aset atau $95 \%$ dalam kondisi baik dan 35 aset atau 5 $\%$ dalam kondisi rusak ringan.

b. Panjang saluran yang terdapat pada Sub Sistem II sepanjang 55.531,47 m, $53.480,42 \mathrm{~m}$ atau $96 \%$ diantaranya berfungsi dengan baik dan hanya sekitar 2,051,05 atau sekitar 4\% dalam kondisi rusak ringan.

c. Organisasi yang ada pada wilayah Sub Sistem II terdiri atas 2 GP3A yaitu GP3A Inolubunggandue dan GP3A Wawonua GP3A ini dilakukan untuk mengakomodir luas areal fungsional cukup luas agar mampu mewadahi kelompok tani khususnya P3A yang tersebar luas di wilayah ini.

\section{Sub Sistem III}

Sub sistem III dari hasil penilaian memiliki urutan nilai sebagai berikut :

a. Aspek Air Irigasi menempati urutan pertama dengan nilai 18,26

b. Aspek Sarana dan Prasarana Fisik urutan kedua dengan nilai 16,52

c. Aspek Institusi Pengelola urutan ketiga dengan nilai 16,37

d. Aspek Manajemen Irigasi urutan keempat dengan nilai 15,54 dan,

e. Aspek Pengelola diTingkat Utama/ SDM diurutan kelima dengan nilai 11,19 .

Dan untuk lebih jelasnya dapat dilihat pada tabel 3.6. berikut ini : 


\begin{tabular}{|c|c|c|c|c|c|}
\hline \multirow{2}{*}{ No } & \multirow{2}{*}{ Kode } & \multirow{2}{*}{ Sub Kriteria } & \multirow{2}{*}{$\begin{array}{l}\begin{array}{l}\text { Bobot } \\
\text { Sub }\end{array} \\
\text { Kriteria }\end{array}$} & \multicolumn{2}{|c|}{$\underline{\text { Sub Sistem III }}$} \\
\hline & & & & $\begin{array}{l}\text { Nilai } \\
\text { Petani }\end{array}$ & Total \\
\hline 1 & 2 & 3 & 4 & 5 & $\begin{array}{c}6=4 \\
\times 5\end{array}$ \\
\hline 1 & A1 & Ketersediaan Debit & 0,0902 & 84,67 & 7,64 \\
\hline 2 & $\mathrm{~A} 2$ & Kualitas Air Irigasi & 0,0224 & 84,33 & 1,89 \\
\hline 3 & A3 & Sistem, Penyediaan Air & 0,0571 & 84,4 & 4,82 \\
\hline 4 & A4 & Stabilitas Penyediaan & 0,027 & 80,6 & 2,17 \\
\hline \multirow[t]{2}{*}{5} & A5 & Kehilangan Air & 0,0221 & 79 & 1,75 \\
\hline & & Air Irigasi & 0,219 & & 18,26 \\
\hline 6 & $\mathrm{~S} 1$ & Kondisi dan Fungsi Jaringan & 0,0797 & 76,73 & 6,12 \\
\hline 7 & $\mathrm{~S} 2$ & Saluran Pembawa & 0,0491 & 75,33 & 3,7 \\
\hline 8 & S3 & Bangunan pada Saluran Pembawa & 0,0367 & 75,93 & 2,79 \\
\hline 9 & $\mathrm{~S} 4$ & Saluran Pembuang dan Bangunannya & 0,0245 & 70,4 & 1,73 \\
\hline 10 & S5 & Jalan Inspeksi & 0,0162 & 70 & 1,14 \\
\hline 11 & S6 & Kantor, Perumahan, Gudang & 0,0096 & 62,2 & 0,6 \\
\hline \multirow[t]{2}{*}{12} & S7 & Peralatan Penunjang OP & 0,0068 & 67,6 & 0,46 \\
\hline & & Sarana dan Prasarana Fisik & 0,223 & & 16,52 \\
\hline 13 & M1 & Pengumpulan Data, Pembagian Air & 0,0107 & 72,13 & 0,77 \\
\hline 14 & M2 & Priode Pembagian Air & 0,0619 & 78,33 & 4,85 \\
\hline 15 & M3 & Rencana Pola Tanam & 0,044 & 86,73 & 3,82 \\
\hline 16 & M4 & Partisipasi Petani & 0,022 & 71,07 & 1,56 \\
\hline 17 & M5 & Pemeliharaan dan Rehabilitasi & 0,0297 & 76,2 & 2,26 \\
\hline 18 & M6 & Iuran OP & 0,0159 & 65,47 & 1,04 \\
\hline 19 & M7 & Sistem Informasi dan Monitoring & 0,0074 & 71,07 & 0,53 \\
\hline 20 & M8 & Sistem Pengambilan Keputusan & 0,0051 & 81,8 & 0,42 \\
\hline \multirow[t]{2}{*}{21} & M9 & $\begin{array}{l}\text { Penerapan Sistem Insentif dan } \\
\text { Disentif }\end{array}$ & 0,0038 & 74,47 & 0,28 \\
\hline & & Manajemen Irigasi & $\mathbf{0 , 2 0 1}$ & & 15,54 \\
\hline 22 & $\mathrm{I} 1$ & Dinas PU Subdin SDA Kabupaten & 0,0952 & 80,4 & 7,65 \\
\hline 23 & $\mathrm{I} 2$ & Komisi Irigasi & 0,0329 & 80,07 & 2,64 \\
\hline 24 & $\mathrm{I} 3$ & Unit Pelaksana Teknis & 0,0566 & 81,4 & 4,61 \\
\hline \multirow[t]{2}{*}{25} & $\mathrm{I} 4$ & Perkumpulan Petani Pengguna Air & 0,0196 & 75,2 & 1,47 \\
\hline & & Institusi Pengelola Irigasi & 0,204 & & 16,37 \\
\hline 26 & $\mathrm{P} 1$ & Kuantitas & 0,0723 & 76,53 & 5,53 \\
\hline 27 & $\mathrm{P} 2$ & Kualitas (Kompetensi) & 0,0407 & 76,2 & 3,1 \\
\hline 28 & P3 & Hubungan antar Masyarakat & 0,0132 & 74,8 & 0,99 \\
\hline \multirow[t]{2}{*}{29} & $\mathrm{P} 4$ & Regenerasi & 0,0236 & 66,53 & 1,57 \\
\hline & & Pengelola di Tingkat Utama/ SDM & $\mathbf{0 , 1 5}$ & & 11,19 \\
\hline
\end{tabular}


Dari hasil penilaian pada Sub Sistem III JI DI Wawotobi dapat dijelaskan sebagai berikut :

a. Kondisi aset Sarana dan Prasarana yang terdapat pada Sub Sistem III intake Kiri Bungguosu sebagian besar dalam kondisi baik, dari 577 aset yang ada pada Wilayah Sub Sistem III terdapat 542 aset atau 95\% dalam kondisi baik 13 aset atau $5 \%$ dalam kondisi rusak ringan hingga rusak sedang .

b. Panjang saluran yang terdapat dalam Sub Sistem III sepanjang 78.608.54 $\mathrm{m}, 77.041,54$ atau 98\% diantaranya berfungsi dengan baik dan hanya sekitar 1.567 atau 2\% dalam kondisi rusak ringan.

c. Organisasi yang ada pada wilayah Sub Sistem III terdiri atas 4 GP3A yaitu GP3A Tolowonua, GP3A Makmur Jaya, GP3A Sanggolembae dan GP3A Sumber Makmur hal ini dilakukan untuk mengakomodir luas areal fungsional yang ada di DI Wawotobi Sub Sistem III agar mampu mewadahi kelompok tani khususnya P3A yang tersebar luas di daerah ini.

Dari penilaian ke 3 sub sistem yang tersebut diatas dapat diurut berdasarkan ranking sebagaimana pada tabel 4.7. berikut ini :

Tabel 3.7. Ranking Nilai pada JI di DI Wawotobi

\begin{tabular}{cccccccc}
\hline \multirow{2}{*}{ Sub Sistem } & A & S & M & I & P & Total & Rangking \\
\hline $\begin{array}{c}\text { Sub Sistem } \\
\text { I } \\
\text { Sub Sisitem } \\
\text { II } \\
\text { Sub Sistem } \\
\text { III }\end{array}$ & 16,64 & 16,57 & 14,35 & 15,28 & 10,01 & 72,84 & III \\
& 18,26 & 16,52 & 15,54 & 16,37 & 11,19 & 77,88 & I \\
\hline
\end{tabular}




\section{ISSN.1907-753X}

Tabel 3.8 Rekapituasi Hasil Penilaian pada 3 Sub Sistem

\begin{tabular}{|c|c|c|c|c|c|c|c|c|c|}
\hline \multirow{3}{*}{ No } & \multirow{3}{*}{ Kode } & \multirow{3}{*}{ Sub Kriteria } & \multirow{3}{*}{$\begin{array}{l}\begin{array}{l}\text { Bobot } \\
\text { Sub }\end{array} \\
\text { Kriteria }\end{array}$} & \multirow{2}{*}{\multicolumn{2}{|c|}{$\underline{\text { Sub Sistem I }}$}} & \multirow[b]{3}{*}{$\begin{array}{l}\text { Nilai } \\
\text { Petani }\end{array}$} & \multirow{3}{*}{$\frac{\text { II }}{\text { Total }}$} & \multirow{3}{*}{$\begin{array}{c}\text { Sub Sis } \\
\text { Nilai } \\
\text { Petani }\end{array}$} & \multirow{3}{*}{\begin{tabular}{|l} 
Ttetm III \\
\end{tabular}} \\
\hline & & & & & & & & & \\
\hline & & & & $\begin{array}{l}\text { Nilai } \\
\text { Petani }\end{array}$ & Total & & & & \\
\hline 1 & 2 & 3 & 4 & 5 & $6=4 \times 5$ & 5 & $6=4 \times 5$ & 5 & $\begin{array}{c}6=4 \\
\times 5\end{array}$ \\
\hline 1 & $\mathrm{~A} 1$ & Ketersediaan Debit & 0,0902 & 76,33 & 6,89 & 80,2 & 7,23 & 84,67 & 7,64 \\
\hline 2 & $\mathrm{~A} 2$ & Kualitas Air Irigasi & 0,0224 & 78,2 & 1,75 & 84,6 & 1,89 & 84,33 & 1,89 \\
\hline 3 & $\mathrm{~A} 3$ & Sistem, Penyediaan Air & 0,0571 & 74 & 4,22 & 80,07 & $<, 57$ & 84,4 & 4,82 \\
\hline 4 & A4 & Stabilitas Penyediaan & 0,027 & 74,67 & 2,01 & 80,53 & 2,17 & 80,6 & 2,17 \\
\hline \multirow[t]{2}{*}{5} & A5 & Kehilangan Air & 0,0221 & 79,67 & 1,76 & 79,87 & 1,77 & 79 & 1,75 \\
\hline & & Air Irigasi & 0,219 & & 16,64 & & 17,64 & & 18,26 \\
\hline 6 & $\mathrm{~S} 1$ & Kondisi dan Fungsi Jaringan & 0,0797 & 74 & 5,9 & 72,67 & $\leq, 79$ & 76,73 & 6,12 \\
\hline 7 & $\mathrm{~S} 2$ & Saluran Pembawa & 0,0491 & 76 & 3,73 & 70,8 & $\{, 47$ & 75,33 & 3,7 \\
\hline 8 & S3 & Bangunan pada Saluran Pembawa & 0,0367 & 79 & 2,9 & 72,13 & 2,65 & 75,93 & 2,79 \\
\hline 9 & S4 & $\begin{array}{l}\text { Saluran Pembuang dan } \\
\text { Bangunannya }\end{array}$ & 0,0245 & 75,53 & 1,85 & 66,67 & 1,63 & 70,4 & 1,73 \\
\hline 10 & S5 & Jalan Inspeksi & 0,0162 & 67,27 & 1,09 & 68,93 & 1,12 & 70 & 1,14 \\
\hline 11 & S6 & Kantor, Perumahan, Gudang & 0,0096 & 69,13 & 0,66 & 65,93 & $(, 63$ & 62,2 & 0,6 \\
\hline \multirow[t]{2}{*}{12} & S7 & Peralatan Penunjang OP & 0,0068 & 64,13 & 0,44 & 63,87 & $(, 44$ & 67,6 & 0,46 \\
\hline & & Sarana dan Prasarana Fisik & 0,223 & & 16,57 & & 15,73 & & 16,52 \\
\hline 13 & M1 & Pengumpulan Data, Pembagian Air & 0,0107 & 67,2 & 0,72 & 67,67 & $(, 73$ & 72,13 & 0,77 \\
\hline 14 & M2 & Priode Pembagian Air & 0,0619 & 74,67 & 4,62 & 79,13 & $<, 89$ & 78,33 & 4,85 \\
\hline 15 & M3 & Rencana Pola Tanam & 0,044 & 71,33 & 3,14 & 85,53 & $\therefore, 77$ & 86,73 & 3,82 \\
\hline 16 & M4 & Partisipasi Petani & 0,022 & 70,67 & 1,56 & 66,47 & 1,46 & 71,07 & 1,56 \\
\hline 17 & M5 & Pemeliharaan dan Rehabilitasi & 0,0297 & 71 & 2,11 & 70,2 & 2,09 & 76,2 & 2,26 \\
\hline 18 & M6 & Iuran OP & 0,0159 & 66,27 & 1,05 & 68,6 & 1,09 & 65,47 & 1,04 \\
\hline 19 & M7 & Sistem Informasi dan Monitoring & 0,0074 & 66,6 & 0,5 & 62,8 & $(, 47$ & 71,07 & 0,53 \\
\hline 20 & M8 & Sistem Pengambilan Keputusan & 0,0051 & 71,6 & 0,36 & 74,53 & $(, 38$ & 81,8 & 0,42 \\
\hline \multirow[t]{2}{*}{21} & M9 & $\begin{array}{l}\text { Penerapan Sistem Insentif dan } \\
\text { Disentif }\end{array}$ & 0,0038 & 77 & 0,29 & 69,07 & $(, 26$ & 74,47 & 0,28 \\
\hline & & Manajemen Irigasi & 0,201 & & 14,35 & & 15,14 & & 15,54 \\
\hline 22 & I1 & Dinas PU Subdin SDA Kabupaten & 0,0952 & 74,6 & 7,1 & 75,8 & 7,21 & 80,4 & 7,65 \\
\hline 23 & $\mathrm{I} 2$ & Komisi Irigasi & 0,0329 & 77 & 2,53 & 78,13 & 2,57 & 80,07 & 2,64 \\
\hline 24 & I3 & Unit Pelaksana Teknis & 0,0566 & 74,27 & 4,21 & 79,87 & 4,52 & 81,4 & 4,61 \\
\hline \multirow[t]{2}{*}{25} & I4 & Perkumpulan Petani Pengguna Air & 0,0196 & 73,33 & 1,44 & 73,2 & 1,44 & 75,2 & 1,47 \\
\hline & & Institusi Pengelola Irigasi & 0,204 & 299,2 & 15,28 & & 15,74 & & 16,37 \\
\hline 26 & $\mathrm{P} 1$ & Kuantitas & 0,0723 & 67,33 & 4,87 & 70,6 & 5,1 & 76,53 & 5,53 \\
\hline 27 & $\mathrm{P} 2$ & Kualitas (Kompetensi) & 0,0407 & 64 & 2,61 & 74,8 & $£, 05$ & 76,2 & 3,1 \\
\hline 28 & $\mathrm{P} 3$ & Hubungan antar Masyarakat & 0,0132 & 70,67 & 0,93 & 70,8 & $(, 94$ & 74,8 & 0,99 \\
\hline \multirow[t]{4}{*}{29} & $\mathrm{P} 4$ & Regenerasi & 0,0236 & 67,93 & 1,6 & 66,47 & 1,57 & 66,53 & 1,57 \\
\hline & & $\begin{array}{l}\text { Pengelola di Tingkat Utama/ } \\
\text { SDM }\end{array}$ & 0,15 & & 10,01 & & 10,65 & & 11,19 \\
\hline & & JUMLAH & 100 & & 72,84 & & $i 4,9$ & & 77,88 \\
\hline & & URUTAN NILAI & & & III & & II & & I \\
\hline
\end{tabular}


Selanjutnya perbandingan antara nilai penelitian pada JI di DI Wawotobi Kinerja Sistem Irigasi berdasarkan berikut ini : Permen PU 13/2012 dengan hasil dari

Tabel 3.9 Perbandingan Permen PU 13/2012 dengan Hasil Penelitian

\begin{tabular}{|c|c|c|c|c|c|c|c|c|c|}
\hline \multirow[b]{2}{*}{ No } & \multirow{2}{*}{$\begin{array}{c}\text { INDEKS KINERJA SISTEM } \\
\text { IRIGASI } \\
\text { PERMEN PUPR 12/ } 2012\end{array}$} & \multirow{2}{*}{$\begin{array}{l}\text { Nilai } \\
\text { Max }\end{array}$} & \multirow{2}{*}{$\begin{array}{l}\text { Nilai } \\
\text { BWSS } \\
\text { IV }\end{array}$} & \multirow[b]{2}{*}{ No } & \multirow[b]{2}{*}{ HASIL PENELITIAN } & \multirow{2}{*}{$\begin{array}{c}\text { Bobot } \\
\text { Indikator }\end{array}$} & \multicolumn{3}{|c|}{ NILAI SUB SISTEM } \\
\hline & & & & & & & $\begin{array}{l}\text { Sistem } \\
\quad \text { I }\end{array}$ & $\begin{array}{l}\text { Sistem } \\
\text { II }\end{array}$ & $\begin{array}{l}\text { Sistem } \\
\text { III }\end{array}$ \\
\hline $\mathbf{I}$ & PRASARANA FISIK & 45 & 32,6 & $\mathbf{I}$ & AIR IRIGASI & 22 & 16,63 & 17,63 & 18,27 \\
\hline 1 & Bangunan Utama & 13 & 11,22 & 1 & Ketersediaan Debit & 9 & 6,89 & 7,23 & 7,64 \\
\hline 2 & Saluran Pembawa & 10 & 7,5 & 2 & Kualitas Air Irigasi & 2 & 1,75 & 1,89 & 1,89 \\
\hline 3 & Banguna pada Saluran Pembawa & 9 & 6,48 & 3 & Sistem, Penyediaan Air & 6 & 4,22 & 4,57 & 4,82 \\
\hline 4 & Saluran Pembuang & 4 & 1,5 & 4 & Stabilitas Penyediaan & 3 & 2,01 & 2,17 & 2,17 \\
\hline 5 & Jalan Masuk/ Inspeksi & 4 & 2,55 & 5 & Kehilangan Air & 2 & 1,76 & 1,77 & 1,75 \\
\hline 6 & Kantor, Perumaha dan Gudang & 5 & 3,15 & II & $\begin{array}{l}\text { SARANA DAN } \\
\text { PRASARANA FISIK }\end{array}$ & 23 & 16,57 & 15,73 & 16,54 \\
\hline II & PRODUKTIFITAS TANAM & 15 & 12,91 & 1 & Kondisi dan Fungsi Jaringan & 8 & 5,9 & 5,79 & 6,12 \\
\hline 1 & Faktor K & 9 & 9 & 2 & Saluran Pembawa & 5 & 3,73 & 3,47 & 3,7 \\
\hline 2 & Realisasi Tanam & 4 & 2,4 & 3 & $\begin{array}{l}\text { Bangunan pada Saluran } \\
\text { Pembawa }\end{array}$ & 4 & 2,9 & 2,65 & 2,79 \\
\hline 3 & Produksi Padi & 2 & 1,51 & 4 & Saluran Pembuang & 2 & 1,85 & 1,63 & 1,73 \\
\hline III & SARANA PENUNJANG & 10 & 7,4 & 5 & Jalan Inspeksi & 2 & 1,09 & 1,12 & 1,14 \\
\hline 1 & Peralatan OP & 4 & 2 & 6 & Kantor, Perumahan, Gudang & 1 & 0,66 & 0,63 & 0,6 \\
\hline 2 & Transportasi & 2 & 1,9 & 7 & Peralatan Penunjang OP & 1 & 0,44 & 0,44 & 0,46 \\
\hline 3 & Alat- alat Kantor & 2 & 2,3 & III & MANAJEMEN IRIGASI & 20 & 14,35 & 15,14 & 15,53 \\
\hline 4 & Alat Komunikasi & 2 & 1,2 & 1 & Pengumpulan Data & 1 & 0,72 & 0,73 & 0,77 \\
\hline IV & ORGANISASI PERSONALIA & 15 & 11,25 & 2 & Priode Pembagian Air & 5 & 4,62 & 4,89 & 4,85 \\
\hline 1 & Organisasi OP & 5 & 4,4 & 3 & Rencana Pola Tanam & 4 & 3,14 & 3,77 & 3,82 \\
\hline 2 & Personalia & 10 & 6,85 & 4 & Partisipasi Petani/ P3A & 2 & 1,56 & 1,46 & 1,56 \\
\hline $\mathbf{V}$ & DOKUMENTASI & 5 & 3,5 & 5 & Pemeliharaan dan Rehabilitasi & 3 & 2,11 & 2,09 & 2,26 \\
\hline 1 & Buku Data & 2 & 1,6 & 6 & Iuran OP untuk Perbaikan & 2 & 1,05 & 1,09 & 1,04 \\
\hline 2 & Peta dan Gambar & 3 & 1,9 & 7 & $\begin{array}{l}\text { Sistem Informasi dan } \\
\text { Monitoring }\end{array}$ & 1 & 0,5 & 0,47 & 0,53 \\
\hline VI & $\begin{array}{l}\text { PERKUMPULAN PETANI } \\
\text { PEMAKAI AIR }\end{array}$ & 10 & 7,3 & 8 & Sistem Pengambilan Keputusan & 1 & 0,36 & 0,38 & 0,42 \\
\hline 1 & $\begin{array}{l}\text { GP3AAIP3A sudah berbadan } \\
\text { Hukum }\end{array}$ & 1,5 & 1,35 & 9 & $\begin{array}{l}\text { Penerapan Sistem Insentif dan } \\
\text { Disentif }\end{array}$ & 1 & 0,29 & 0,26 & 0,28 \\
\hline 2 & Kondisi Kelembagaan GP3A & 0,5 & 0,45 & IV & $\begin{array}{l}\text { INSTITUSI PENGELOLA } \\
\text { IRIGASI }\end{array}$ & 20 & 15,28 & 15,74 & 16,37 \\
\hline $\begin{array}{l}3 \\
4\end{array}$ & $\begin{array}{l}\text { Rapat Ulu ulu } \\
\text { P3A aktif mengikuti survey }\end{array}$ & 2 & 1,4 & 1 & Dinas SDA Kabupaten Konawe & 9 & 7,1 & 7,21 & 7,65 \\
\hline $\begin{array}{l}4 \\
5\end{array}$ & $\begin{array}{l}\text { Penelusuran Jařingan } \\
\text { Partisipasi P3A memperbaiki } \\
\text { Jaringan }\end{array}$ & 1 & 0,2 & 2 & $\begin{array}{l}\text { Komisi Irigasi Konawe } \\
\text { Unit Pelaksana Teknis Daerah }\end{array}$ & 3 & 2,53 & 2,57 & 2,64 \\
\hline 6 & $\begin{array}{l}\text { Iuran OP untuk memperbaiki } \\
\text { Jaringan Tersier }\end{array}$ & 2 & 1,6 & 3 & Konawe & 6 & 4,21 & 4,52 & 4,61 \\
\hline \multirow[t]{6}{*}{7} & $\begin{array}{l}\text { Partisipasi P3A di Perencanaan Tata } \\
\text { Tanam }\end{array}$ & 2 & 1,6 & 4 & Petani/ P3A & 2 & 1,44 & 1,44 & 1,47 \\
\hline & & 1 & 0,7 & $\mathbf{v}$ & $\begin{array}{l}\text { PENGELOLA DITINGKAT } \\
\text { UTAMA/SDM }\end{array}$ & 15 & 10,01 & 10,66 & 11,39 \\
\hline & & & & 1 & Kuantitas (Jumlah Petugas) & 7 & 4,87 & 5,1 & 5,53 \\
\hline & & & & 2 & Kualitas (Kompetensi) & 5 & 2,61 & 3,05 & 3,1 \\
\hline & & & & 3 & Hubungan antar Masyarakat & 1 & 0,93 & 0,94 & 0,99 \\
\hline & Total & & & 4 & Regenerasi (Petugas) & 2 & 1,6 & 1,57 & 1,57 \\
\hline & & 100 & 74,96 & & & 100 & 72,84 & 74,9 & 77,9 \\
\hline
\end{tabular}


Hasil Perbandingan Indeks Kinerja Sistem Irigasi antara Permen PU No. 13/2012, pada tabel 5.56. dengan hasil penelitian adalah : Untuk Indikator Prasarana Fisik Permen PU No. 13/2012 menargetkan nilai maksimun $45 \%$ nilai dari BWSS IV 32,6\%, sedangkan hasil penelitian dengan Indikator Sarana dan Prasarana Fisik tidak termasuk Sarana Penunjang OP untuk Sub Sistem I $16,57 \%$, Sub Sistem II $15.73 \%$ dan Sub Sistem III 16,54\%, Indikator Produktifitas Tanam dengan 3 Sub Indikator (Faktor K, Realisasi Tanam dan Produksi Padi) untuk Permen PU No. 13/2012 menargetkan nilai maksimum $15 \%$, dari BWSS IV dengan nilai 12, $91 \%$, sedangkan hasil penelitian Indikator Air Irigasi dengan 5 Sub Indikator (Ketersediaan Debit/Faktor K, Kualitas Air, Sistem Penyediaan Air, Stabilitas Penyediaan Air, dan Kehilangan Air) diperoleh nilai untuk Sub Sistem I 16,63\%, Sub Sistem II $17,63 \%$ dan Sub Sistem III sebesar $18,27 \%$, nilai yang diperoleh dari penelitian lebih tinggi dibandingkan dengan Permen PU begitu juga penilaian dari BWSS IV disebabkan dari Sub Indikator yang digunakan dalam penelitian lebih banyak dengan pedoman dari penilaian kinerja untuk Pengembangan dan Pengelolaan Sistem Irigasi berdasarkan lima (5) pilar. Selanjutnya untuk Indikator Sarana Penunjang yang terdiri dari 4 Sub Indikator (Peralatan OP, Transportasi, Alat Kantor dan Alat Komunikasi) Permen PU No 13/2012 menargetkan nilai maksimun $10 \%$ nilai dari BWSS IV sebesar 7,4\%, sedangkan hasil penelitian dengan Indikator Sarana dan Prasaran Fisik dengan 1 Sub Indikator saja yaitu (Peralatan Pununjang OP) untuk Sub Sistem I 0,44\%, Sub Sistem II 0,44\% dan Sub Sistem III 0,46\%, Untuk nilai Indikator Organisasi Personalia yang terdiri atas 2 Sub Indikator yaitu (Organisasi OP dan Personalia) Permen PU No. 13/2012 menargetkan nilai maksimun $15 \%$ nilai dari BWSS IV sebesar 11,25\% sedangkan hasil penelitian dengan Indikator Institusi Pengelola dengan 4 Sub Indikator (Dinas SDA Kabupaten, Komisi Irigasi dan Unit Pelaksana) Sub Sistem I nilai $15,28 \%$, Sub Sistem II nilai $15,74 \%$ dan Sub Sistem III nilai $16,37 \%$, Untuk nilai Indikator Dokumentasi dengan 3 Sub Kriteria (Buku Data, Peta dan Gambar) Permen PU No. 13/2012 menargetkan nilai maksimun $5 \%$ dan nilai dari BWSS IV sebesar 3,5 \% sedangkan hasil penelitian dengan Indikator Manajemen Irigasi dengan 2 Sub Indikator (Sistem Informasi dan Pengumpulan Data) untuk Sub Sistem I nilai 1,22\%, Sub Sistem II nilai $1,20 \%$ dan Sub Sistem III nilai $1,30 \%$, Untuk nilai Indikator Perkumpulan Petani Pemakai Air/P3A dengan 7 Sub Indikator (GP3A/P3A sudah berbadan Hukum, Kondisi Kelembagaan GP3A, Rapat Ulu ulu, P3A Aktif ikut serta dalam Survey Jaringan, Partisipasi P3A dalam Perbaikan Jaringan dan Bencana Alam, Partisipasi P3A dalam Rencana Pola Tanam) Permen PU menargetkan nilai maksimun $10 \%$, nilai dari BWSS IV dengan nilai $7,3 \%$ sedangkan hasil penelitian dengan Indikator Manajemen Irigasi dengan 4 Sub Indikator (Priode 

$\begin{array}{lrr}\text { Pembagian Air, Partisipasi } & \text { P3A, } \\ \text { Pemeliharaan dan Rehabilitasi, } & \text { Iuran }\end{array}$ OP) dan Indikator Institusi Pengelola Irigasi dengan Sub Indikator (P3A) yang terdiri dari Sub Sistem I total nilai 7\%, Sub Sistem II nilai $8 \%$ dan Sub Sistem III nilai $8 \%$.

Dari perbandingan tersebut diatas ada beberapa perbedaan yang cukup signifikan antara nilai kinerja berdasarkan Permen PU No. 13/2012 atau yang diperoleh dari BWSS IV dibandingkan dengan hasil penelitian ini disebabkan karena data dari BWSS IV merupakan hasil penilaian tahun 2012 hal ini desebabkan belum adanya data hasil penilaian kinerja yang terbaru yang dikeluarkan oleh BWSS IV, sehingga nilai yang didapatkan dari hasil penelitian 2015 melebihi nilai yang diperoleh dari BWSS IV hasil penilaian tahun 2012. Disamping itu Variabel/Indikator yang dinilai pada Permen PU No. 13/2012 dan Variabel/Indikator yang digunakan pada BWSS IV belum mencerminkan dengan tegas Pengembangan dan Pengelolaan Sistem Irigasi berdasarkan lima (5) pilar yang terdiri dari : Ketersediaan Air, Infrastruktur, Pengelolaan Irigasi, Institusi Irigasi dan Manusia sebagai Pelaku sedangkan hasil penilaian ini sudah mengadaptasi dari kelima sistem yang ada tersebut.

Berdasarkan dari hasil penilaian diatas nampak bahwa meskipun ketersediaan air cukup bagus dari sumbernya dalam hal ini bendung Wawotobi namun tingkat ketersediaan air pada sub sistem pada DI Wawotobi yang ada belum merata hal ini disebabkan beberapa faktor diantaranya : Sistem Penyediaan Air dan Stabilitas Penyediaan Air belum optimal, sarana dan Prasarana Fisik yang terdiri dari Kondisi dan Fungsi Jaringan, Saluran Pembawa, Bangunan pada Saluran Pembawa dan Saluran Pembuang juga belum berfungsi optimal akibat dari lemahnya Manajemen Irigasi terutama pada bagian Priode Pembagian Air, Rencana Pola Tanam, Partisipasi P3A, Pemeliharaan dan Rehabilitasi, Iuran OP, Sistem Informasi dan Monitoring, Sistem Pengambilan Keputusan dan penerapan Insentif dan Disentif belum sepenuhnya dijalankan dengan baik hal ini diakibat karena kurangnya personil Unit Pelaksana Teknis Daerah serta Dinas SDA Kabupaten Konawe yang memenuni standar kualifikasi, demikian juga pada pengelolaan diTingkat Utama secara Kuantitas masih kurang serta dari segi Kualitas belum memadai sehingga kedua faktor tersebut perlu terus ditingkatkan dari segi kuantitas yang berkualitas dengan kursus/pelatihan yang berkelanjutan.

\section{Simpulan}

\section{Kondisi eksisting JI di DI Wawotobi.}

a. Air Irigasi :

Debit Andalan sungai Konaweha pada 2012 pengamatan rerata $68.58 \mathrm{~m}^{3} /$ detik. Debit tertinggi $139,48 \mathrm{~m}^{3} /$ detik pada priode 1 bulan April dan terendah 24,02 $\mathrm{m}^{3} /$ detik terjadi tengah bulan II September. Kebutuhan air untuk mengairi sawah seluas 9.872,54 ha, rerata sebesar $10,35 \mathrm{~m}^{3} /$ detik. 
b. Prasarana Fisik :

1). Panjang Saluran $153.156 \mathrm{~m}$, Kondisi saluran 149,538 m atau $97,64 \%$ berfungsi baik dan $3.618 \mathrm{~m}$ atau $2,36 \%$ mengalami fungsi menurun akibat kerusakan ringan hingga rusak sedang.

2). Bangunan Aset berjumlah 984 buah 937 atau 95,12\% berfungsi baik dan 47 atau $4,88 \%$ buah aset mengalami penurunan fungsi karena rusak ringan hingga rusak sedang.

3). Manajemen Irigasi :

Prosentase rata-rata realiasasi musim tanam pada DI Wawotobi sebesar 58\%, masih banyak lahan potensial yang belum diolah jadi sawah karena dana dari Pusat dan Daerah terbatas untuk pembukaan lahan/sawah baru serta lahan potensial sebagian telah alih fungsi. Kesadaran masyarakat belum sepenuhnya mengacuh pada pedoman pola tanam yang telah ditentukan oleh pemerintah, dalam hal ini yang diwakili oleh Komisi Irigasi Kabupaten Konawe, sebagian petani mengolah lahan sawah mereka masih menganut sistem yang mereka yakini dengan cara mereka masing-masing, misalnya menentukan hari dan tanggal yang baik menurut kepercayaan mereka sehingga pola tanam agak sulit dilaksanakan secara serentak dengan waktu pola tanam yang padat. Alat pengolah lahan masih sangat terbatas antara lain trakctor atau handtraktor sehingga petani tidak jarang menunggu giliran dari pihak penyedia jasa olah lahan dalam hal ini pemilik traktor atau handtraktor untuk pengolahan lahan sawah mereka secara bergantian/ bergiliran.

4). Institusi Pengelola Irigasi

Institusi pengelola di Kabupaten Konawe terdiri atas : Dinas PU dan Tata Ruang Sub Dinas SDA Kabupaten Konawe, Komisi Irigasi, Unit Pelaksana Teknis Daerah/UPTD serta P3A sebagai pengguna sekaligus pengelola irigasi diwilayah mereka masing masing. Keempat komponen pengelola irigasi yang ada sudah berjalan sesuai dengan fungsi dan tanggung jawabnya, namun sampai saat ini masih terdapat kekurangan yang perlu dibenahi dan diharapkan dengan pembenahan yang dilakukan kedepannya akan lebih baik dari sebelumnya.

5). Pengelola diTingkat Utama/ SDM.

Pengelola ditingkat utama dikategorikan dalam 4 bagian yaitu kuantitas, kualitas, hubungan antar masyarakat dan regenerasi dari keempat kategori yang ada 3 
diantaranya saling terkait satu dengan yang lainnya yakni kuantitas, kualitas, dan regenerasi ketiga unsur ini harus dipenuhi dan tetap dijaga agar pengelolaan sistem JI DI Wawotobi tetap terjaga dan berkelanjutan serta berjalan dengan baik, sedangkan kategori hubungan dengan masyarakat sangat terkait dengan personalisasi dan kualitas dari pengelola itu sendiri, semakin berkualitas dengan seringnya diadakan pelatihan personal yang dimiliki oleh pengelola diharapkan semakin baik hubungannya dengan masyarakat dimanapun mereka ditugaskan.

\section{Penentuan Skoring}

Untuk menentukan skoring dan indikator terhadap faktor-faktor yang mempengaruhi dalam penilaian kinerja sistem JI pada DI Wawotobi dengan menggunakan 29 bobot indikator dari penilaian petani dikalikan dengan nilai pendapat dari expert/para ahli dibidangnya yang hasilnya masing-masing dapat diurutkan dengan prioritas sebagai berikut : Dinas PU Subdin SDA menempati urutan pertama dengan bobot 0,0952, selanjutnya secara berturut turut diurutan berikutnya adalah, Ketersediaan Debit dengan bobot 0,0902, Kondisi dan Fungsi Jaringan dengan bobot 0,0797, Kuantitas dengan bobot 0,0723, Priode Pembagian Air dengan bobot
0,0619, Sistem Penyediaan Air dengan bobot 0,0571, Unit Pelaksana Teknis Daerah dengan bobot 0,0566, Saluran Pembawa dengan bobot 0,0491, Perencanaan Pola Tanam dengan bobot 0,0440, Kualitas/ Kompetensi dengan bobot 0,0407, Saluran Pembuang dengan bobot, 0,0367, Komisi Irigasi dengan bobot 0,0329,Pemeliharaan dan Rehabilitasi dengan bobot 0,0297, Stabilitas Penyediaan Air dengan bobot 0,0270 Bangunan pada Saluran Pembawa dengan bobot 0,0245, Regenerasi dengan bobot 0,0236, Kualitas Air Irigasi dengan bobot 0,0224, P3A dengan bobot 0,0155, Kehilangan Air dengan bobot 0,0221, Partisipasi Petani dengan bobot 0,0220, Petani Pengguna Air dengan bobot 0,0196, Jalan Inspeksi dengan bobot 0,0162, Iuran OP dengan bobot 0,0159, Hubungan antar Masyarakat dengan bobot 0,0132, Pengumpulan Data, Perhitungan, Kebutuhan Air dengan bobot 0,0107, Kantor Perumahan, Gudang, dengan bobot 0,0096, Sistem Informasi dan Monitoring dengan bobot 0,0074, Peralatan Penunjang OP dengan bobot 0,0068, Sistem Pengambilan Keputusan dengan bobot 0,0051, dan urutan terakhir atau bobot terendah Sistem Insentif dan Disentif dengan bobot 0,0038 .

\section{Hasil Penilaian 3 Sub Sistem di DI Wawotobi}

a. Dari hasil penilaian dengan menggunakan 29 indikator maka dapat diperoleh hasil sabagai berikut : Sub Sistem III Wilayah 
Intake Kiri Bungguosu dengan nilai 77,88 menempati peringkat I, Sub Sistem II Wilayah Intake Kiri Unaaha A dan Unaaha B dengan nilai 74,90 Peringkat kedua, dan Sub Sistem I Wilayah Intake Kanan Uepai dan Tawamelewe dengan nilai 72,84. menempati peringkat ketiga berdasarkan hasil penelitian serta mengacu pada Penilaian Indeks Kinerja Permen PUPR 12/2015 maka Indeks Kinerja Sistem JI DI Wawotobi termasuk dalam kategori baik dengan nilai rata-rata dari ketiga Sub sistem yang ada sebesar $75,21 \%$.

b. Berdasarkan dari hasil penilaian meskipun ketersediaan air cukup bagus namun tingkat ketersediaan air pada sub sistem pada DI Wawotobi yang ada belum merata hal ini disebabkan beberapa faktor diantaranya : Sistem Penyediaan Air dan Stabilitas Penyediaan Air belum optimal, belum berfungsi optimal akibat dari lemahnya Manajemen Irigasi khususnya pada bagian Priode Pembagian Air, Rencana Pola Tanam, Partisipasi P3A, Pemeliharaan dan Rehabilitasi, Iuran OP, Sistem Informasi dan Monitoring, Sistem Pengambilan Keputusan dan penerapan Insentif dan Disentif belum sepenuhnya dijalankan dengan baik hal ini diakibat karena kurangnya personil Unit Pelaksana Teknis Daerah serta Dinas Sumber Daya Air Kabupaten Konawe yang memenuni standar kualifikasi, demikian juga pada pengelolaan diTingkat Utama secara Kuantitas masih kurang serta dari segi Kualitas belum memadai sehingga kedua faktor tersebut perlu terus ditingkatkan dari segi kuantitas yang berkualitas dengan cara kursus atau pelatihan

\section{DAFTAR PUSTAKA}

Departemen Pekerjaan Umum (2004). Undang-Undang Sumber Daya Air Nomor 7, Departemen Pekerjaan Umum, Jakarta;

Departemen Pekerjaan Umum (2006). Peraturan Menteri Nomor 20 Tentang Irigasi, Departemen Pekerjaan Umum, Jakarta;

Departemen Pekerjaan Umum (2012). Peraturan Menteri Nomor 13/ PRT/M/2012 tentang Pedoman Pengeloaan Irigasi Departemen Pekerjaan Umum, Jakarta;

Departemen Pekerjaan Umum (2015). Peraturan Menteri Nomor 30/ PRT/M/2015 tentang Pedoman Pengembangan Pengeloaan Sistem Irigasi, Departemen Pekerjaan Umum, Jakarta;

Kini, Lidia L (2010). Analisa Penelitian Terhadap Pengelolaan Sistem Irigasi Berdasarkan Konsep Pembangunan Berkelanjutan Pada Daerah Irigasi Tilong di Kabupaten Kupang. Tesis Pascasarjana Jurusan Teknik Sipil, ITS Surabaya. 
Kurniawan, N.A (2013). Evaluasi

Kinerja Sistem Irigasi pada

Daerah Irigasi Bareng

Kabupaten Jombang Provinsi

Jawa Timur. Tesis Pascasarjana

Jurusan Teknik Sipil, ITS

Surabaya

Hasibuan Melayu (2011:12) Manajemen

Sumber Daya Manusia, Jakarta

Saaty.T. (1993)Pengambilan Keputusan Bagi Para Pemimpin, Proses Hirarki Analitik untuk Pengambilan Keputusan dalam Situasi yang Kompleks, Pustaka Binama Prassindo, Jakarta.

Sugiyono, (2009). Metodologi Penelitian Kuantitatif, Kualitatif dan $R \& D$, cetakan ke-7, Alfabeta, Bandung.

Syaifuddin, (2013) Evaluasi Kinerja Daerah Irigasi Wawotobi Kabupaten Konawe Provinsi Sulawesi Tenggara. Jurnal Tesis Teknik Sipil Universitas Sebelas Maret Surakarta.

Vida, O.V (2004). Analisa Keberlanjutan Sistem Irigasi Pasca Penyerahan Kewenangan Pengelolaan Irigasi di Kabupaten Tulang Bawang, Tesis Pascasarjana Jurusan Teknis Sipil, ITS Surabaya. 